\title{
Gendered Innovations in

\section{Gendered Innovations in Orthopaedic Science: Hollywood and Orthopaedics: Through the Glass Ceiling-Darkly}

\author{
Amy L. Ladd MD
}

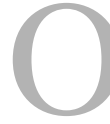
ur current trajectory suggests we are so far behind the curve of bringing women into orthopaedics that it would take a century or so to balance the scales; the previous bastions of neurosurgery and urology are out in front on this issue $[21,28]$. Nothing is more dishearten-

Note from the Editor-in-Chief:

We are pleased to present to readers of

Clinical Orthopaedics and Related

Research ${ }^{\mathbb{R}}$ the latest installment of

"Gendered Innovations in Orthopaedic

Science" by Amy L. Ladd MD. Dr. Ladd is a

Professor in the Department of Orthopaedics at Stanford University. She provides

commentary on sex and gender similarities and differences in orthopaedics.

The author certifies that she, or any members of her immediate family, have no funding or commercial associations (eg, consultancies, stock ownership, equity interest, patent/ licensing arrangements, etc) that might pose a conflict of interest in connection with the submitted article.

All ICMJE Conflict of Interest Forms for authors and Clinical Orthopaedics and Related Research ${ }^{\mathbb{R}}$ editors and board members are on file with the publication and can be viewed on request.

The opinions expressed are those of the writers, and do not reflect the opinion or policy of Clinical Orthopaedics and Related Research $^{\circledR}$ or The Association of Bone and Joint Surgeons ${ }^{\circledR}$. ing to me as a medical student adviser than to see a young woman, exuberant with the discovery of surgery and what it has to offer, choose a nonsurgical specialty. The reason? Lifestyle and culture, however perceived and ill-informed. This is, in my mind, an injustice to our specialty. Suffice it to say we have work to do.

Recall the "glass ceiling." Introduced almost four decades ago, the glass ceiling refers to the visible, but unattainable fruits of leadership to women and minorities in business and traditional white-collar professions [9, 10]. The purported reasons for economic and leadership disparity between men and women in the corporate world, orthopaedics, and society are manifold but similar: Lack of talent, lack of accessibility, lack of flexibility to meet high demands of said industry, and lack of negotiating and networking skills $[3,7,8,18,26]$.

A. L. Ladd MD ( $ه)$

Chase Hand and Upper Limb Center, Stanford University, 770 Welch Rd. Suite 400, Palo Alto, CA 94304-1801, USA e-mail: aladd@stanford.edu
Similar to Fortune 500 companies, Wall Street, the sciences, medicine, and academia, the number of women executives and directors in Hollywood remain appallingly low $[5-8,13,26]$. The hierarchy of the motion picture industry-the business part of the fun-has enough similarities to the sciences and orthopaedics that it is worth a socioeconomic reflection.

In Hollywood, storylines are hyperbolized, characters dramatized, and shoot-'em-up action and internal strife wrench guts and evoke tears. But to me, one of the more unsettling aspects of visual entertainment is that women are often portrayed as sidekicks, love interests, and accomplices who-if they are too pretty, too strong, too much a vixen-either die or get their considerable punishment. I have often wondered, "Why are they so stupid, so helpless, or so fake?" The best and most assertive among them-from Batgirl to Bond Girls-tend to get sidelined, bumped off or even worse, rescued by their male counterparts.

Recent attention has identified the paucity of women in serious acting, directorial, or executive roles, affecting the movie industry at all levels. 


\section{Gendered Innovations in Orthopaedic Science}

According to Maureen Dowd's New York Times exposé on the dearth of women in executive roles in Hollywood [8], the most profound difference exists with women directors. Women comprised of less than $2 \%$ of the directors in blockbusters (considered the 100 topgrossing films) in both 2013 and 2014 [8]. When it comes to salaries, the entertainment industry pay gap mirrors that of the United States, if not the global economy. Despite the Equal Pay Act of 1963, women still realize only 79 cents on the dollar [7, 18], with underrepresented minority women much lower [5].

Generally speaking, in order to chip away at social injustice, we must recognize the disparity and take action. The harder part is taking action. We have seen the emergence of the Civil Rights Act and its offspring the Equal Pay Act (never equalized), the Equal Rights Amendment (never ratified), and Title IX (and all its implications $[16,17])$. New York Times reporter Claire Cain Miller proposes a sea change across the realms of business in order to bridge the pay gap. She recommends: (1) Publishing everyone's pay, (2) coaching negotiation techniques, (3) ignoring previous salaries, (4) making work easier for mothers, (5) building flexible work spaces; and importantly, (6) changing the Equal Pay Act [18]. In science, medicine, academia, and the entertainment industry, egalitarian concepts such as these will speak to the entire body of consumers, patients, and the audience at large.

In healthcare, balancing the workforce and all its economic permutations provides the best opportunity for better business practices, research productivity, and better access to care for our patients across medical and surgical disciplines [2, 23, 27]. Widening the pipeline across the arts, sciences, and corporate world opens doors, and potentially shatters glass ceilings [24]. Residencies in pediatrics, family medicine, obstetrics and gynecology, and psychiatry now offer shared residency or part-time options for women (and men) who have family and other professional obligations $[9,10,22]$. This would extend the total residency in years, but accommodate childrearing and critical life decisions, inclusive of all of the best and brightest. Progressive orthopaedic education will require federal Medicare commitment or novel funding to support flexible residency training. This expansion is a fair ask of a government whose current directives aim to deliver affordable, value-based, and shared decision making across a diverse healthcare team and patient population. Naturally, it will take time and certainly investment beyond our current funding structure, but arguably one well worth the effort.
When women have (the rare) opportunity to lead a film, the investment tends to pay off. It turns out, tapping more women in meaningful roles or behind the lens has a substantial economic impact. The Bechdel test-named after cartoonist Allison Bechdel, who introduced the concept in her comic strip in 1985-is a barometer in film measuring whether (1) at least two women are present, (2) they talk to each other in conversation, and (3) they talk about something other than a man $[4,14,25]$. A study of 2013 blockbusters identified those that passed the test earned a total of USD 4.22 billion, while those that failed earned USD 2.66 billion [25]. Movies that pass the Bechdel Test cost significantly less to produce, and had a $37 \%$ higher return on investment [13].

Cinemas in Sweden recently announced that they would provide Bechdel ratings for movies they show in their theatres in an effort to promote gender equality [1]. Sweden's early adoption of gender equality projects recalls the impact of the Gendered Innovations sex and gender research initiative with granting agencies. The first policies were enacted in Scandinavia at the European Commission's Horizon 2020, the largest EU research and innovation program [11, 12, 15]. In part due to this momentum, the NIH has changed its granting policies and has acknowledged how examining sex 


\section{Gendered Innovations in Orthopaedic Science}

and gender similarities and differences in science saves money and saves lives $[11,12,15,19,20]$.

The business of saving lives and relieving suffering-whether on the silver screen or in the operating room-can only improve when half the talent pool are active participants. An orthopaedic workforce of the future that reflects the diverse patient population it serves-one that it is inclusive of both sexes-will best be equipped to provide breakthrough treatments and innovations for each and every individual.

\section{References}

1. Associated Press. Swedish cinemas take aim at gender bias with Bechdel test rating. Available at: http:// www.theguardian.com/world/2013/nov/ 06/swedish-cinemas-bechdel-test-filmsgender-bias. Accessed February 16, 2016.

2. Bae GH, Lee AW, Park DJ, Maniwa K, Zurakowski D; ASSH Diversity Committee, Day CS. Ethnic and gender diversity in hand surgery trainees. J Hand Surg Am. 2015;40: 790-797.

3. Baldwin K, Namdari S, Bowers A, Keenan MA, Levin LS, Ahn J. Factors affecting interest in orthopedics among female medical students: A prospective analysis. Orthopedics. 2011;34:e919-932.

4. Bechdel Movie Test. Available at: http://bechdeltest.com. Accessed February 16, 2016.
5. Berg M. Everything you need to know about the Hollywood pay gap. Available at: http://www.forbes.com/ sites/maddieberg/2015/11/12/everything-you-need-to-know-about-thehollywood-pay-gap/\#5217370e1fe5. Accessed February 16, 2016.

6. Buckley C. Female producers and directors mean female crew members, film study finds. Available at: http://artsbeat.blogs.nytimes.com/2015/ 10/27/female-producers-and-directorsmean-female-crew-members-filmstudy-finds/. Accessed February 16, 2016.

7. Dargis M. In Hollywood, it's a men's, men's, men's world. Available at: http://www.nytimes.com/ 2014/12/28/movies/in-hollywood-itsa-mens-mens-mens-world.html. Accessed February 16, 2016.

8. Dowd M. The women of Hollywood speak out. Available at: http://www. nytimes.com/2015/11/22/magazine/ the-women-of-hollywood-speak-out. html. Accessed February 16, 2016.

9. Federal Glass Ceiling Commission. Good for business: Making full use of the nation's human capital. Available at: http://www.dol.gov/oasam/ programs/history/reich/reports/ceiling. pdf. Accessed February 16, 2016.

10. Federal Glass Ceiling Commission. Solid investments: Making full use of the nation's human capital. Available at: http://www.dol.gov/oasam/ programs/history/reich/reports/ceiling2.pdf. Accessed February 16, 2016.

11. Gendered Innovations. Gender dimensions in research. Available at: http://genderedinnovations.stanford. edu/terms/dimension.html. Accessed February 16, 2016.

12. Gendered Innovations. Sex and gender analysis policies of major granting agencies. Available at: http://gen deredinnovations.stanford.edu/terms/ dimension.html. Accessed February 16, 2016.

13. Hickey W. The dollar-and-cents case against Hollywood's exclusion of women. Available at: http://fivethirtyeight.com/features/the-dollar-andcents-case-against-hollywoods-exclusion-of-women/. February 16, 2016.

14. Kelly E. The female gaze. Available at: http://www.salon.com/2003/01/30/ gaze_3. Accessed February 16, 2016.

15. Ladd AL. Gendered innovations in orthopaedic science: Sex, lies, and stereotype: In praise of the systematic review. [Published online ahead of print October 19, 2015]. Clin Orthop Relat Res. DOI: 10.1007/ s11999-015-4577-2.

16. Ladd AL. Gendered innovations in orthopaedic science: Title IX education: Book learnin' and bone mendin'. Clin Orthop Relat Res. 2014:472:2586-2589.

17. Ladd AL. The sports bra, the ACL, and Title IX-The game in play. Clin Orthop Relat Res. 2014;472:16811684.

18. Miller CC. How to bridge that stubborn pay gap: Available at: http:// www.nytimes.com/2016/01/17/upshot/ how-to-bridge-that-stubborn-pay-gap. $\mathrm{html}$ ?ref=topics\&_r $=0 . \quad$ Accessed February 16, 2016. 


\section{Gendered Innovations in Orthopaedic Science}

19. National Institute of Health. Consideration of sex as a biological variable in NIH-funded research. Available at: http:/grants.nih.gov/ grants/guide/notice-files/NOT-OD15-102.html. Accessed August 24, 2015.

20. National Institute of Health. Consideration of sex as a biological variable in NIH-funded research. Companion reference. Available at: http://orwh.od.nih.gov/sexinscience/ overview/pdf/NOT-OD-15-102_Guidance.pdf. Accessed August 24, 2015.

21. Okike K, Liu B, Lin YB, Torpey JL, Kocher MS, Mehlman CT, Bhandari M, Biermann JS. The orthopedic gender gap: Trends in authorship and editorial board representation over the past 4 decades. Am J Orthop (Belle Mead NJ). 2012;41:304-310.
22. Peterson LE, Carek P, Holmboe ES, Puffer JC, Warm EJ, Phillips RL. Medical specialty boards can help measure graduate medical education outcomes. Acad Med. 2014;89:840842.

23. Reede JY. A recurring theme: The need for minority physicians. Health Aff (Millwood). 2003;22:91-93.

24. Sanchez E. Workshop encourages young women to pursue engineering and orthopaedics. Available at: http:// www.dailylobo.com/article/2016/02/ workshop-encourages-young-womento-pursue-engineering-and-orthopaedics. Accessed March 7, 2016.

25. Sharma V, Sender H. Hollywood movies with strong female roles make more money. Available at: http://www.vocativ.com/culture/cele'brity/hollywood-movies-strong- female-roles-make-money/. Accessed February 16, 2016.

26. Sherry M. A colleague drank my breast milk and other Wall Street tales. Available at: http://www.nytimes.com/2016/01/24/opinion/acolleague-drank-my-breast-milk-andother-wall-street-tales.html. Accessed February 16, 2016.

27. Simon MA. Racial, ethnic, and gender diversity and the resident operative experience. How can the Academic Orthopaedic Society shape the future of orthopaedic surgery? Clin Orthop Relat Res. 1999; 360:253-259.

28. Van Heest AE, Agel J. The uneven distribution of women in orthopaedic surgery resident training programs in the United States. J Bone Joint Surg Am. 2012;94:e9. 